\title{
Working
}

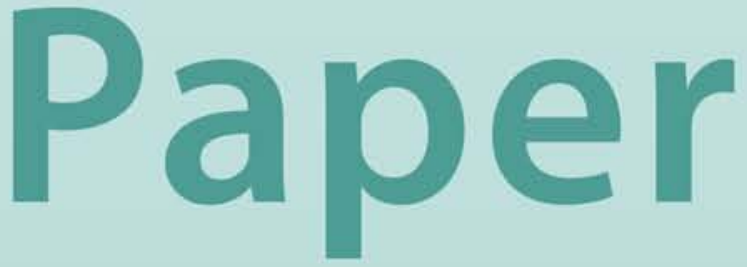




\section{Sovereign Debt Defaults and Financing Needs}

Mark Kruger and Miguel Messmacher 


\title{
IMF Working Paper
}

IMF Executive Director for Antigua and Barbuda, The Bahamas, Barbados, Belize, Canada, Dominica, Grenada, Ireland, Jamaica, St. Kitts and Nevis, St. Lucia, and St. Vincent and the Grenadines, and IMF Institute

\section{Sovereign Debt Defaults and Financing Needs}

Prepared by Mark Kruger and Miguel Messmacher ${ }^{1}$

Authorized for distribution by Ian E. Bennett and Sunil Sharma

March 2004

\begin{abstract}
This Working Paper should not be reported as representing the views of the IMF. The views expressed in this Working Paper are those of the author(s) and do not necessarily represent those of the IMF or IMF policy. Working Papers describe research in progress by the author(s) and are published to elicit comments and to further debate.

We construct a financial vulnerability indicator that is consistent with the theoretical literature on determinants of defaults. It is based on the amount of new foreign financing that is needed to avoid a default or an import adjustment, expressed as a proportion of the country's sources of foreign currency. As the need for new foreign financing increases, so does a country's financial vulnerability. The indicator has a higher correlation with default episodes than other indicators used in previous studies. In addition, the level at which it leads to a high probability of default is comparable across countries.
\end{abstract}

JEL Classification Numbers: F3; F4; G2

Keywords: sovereign debt defaults; financial crisis; early warning indicators; debt sustainability

Authors' E-Mail Addresses: mkruger@,imf.org; mmessmacher@,imf.org

\footnotetext{
${ }^{1}$ The authors wish to thank Paolo Manasse, Nouriel Roubini, and Axel Schimmelpfennig for providing us with some of the data that was used in this study, as well as Adolfo Barajas, Andrew Feltenstein, Tim Kehoe, Vladimir Klyuev, Sunil Sharma, and seminar participants at the IMF Institute for their thoughtful comments and suggestions. All remaining errors are our responsibility.
} 
Contents

I. Introduction

II. Literature Review: Theoretical and Empirical Results

A. Theoretical Analysis of Sovereign Debt Defaults.................................................. 4

B. Empirical Analysis and Forecasting of Debt Defaults .......................................... $\underline{6}$

III. An Indicator of New Financing Needs ............................................................ 9

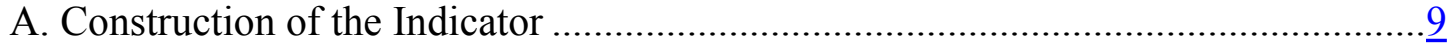

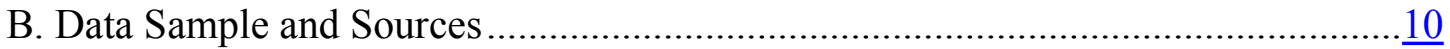

C. Descriptive Statistics and Evolution of the Indicator over Time ...........................11

IV. Estimation and Statistical Results..................................................................... 13

A. Probability of Default Conditional on Different Vulnerability Indicators............... $\frac{13}{14}$

B. Logit Specification and Results................................................................ 14

V. Conclusions and Policy Implications ..................................................................

Tables

1. Summary Statistics of the Proportion of New Financing Needs .....................................21

2. Summary Results from AR(1) Regressions of the Proportion of New Financing

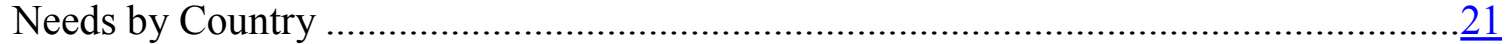

3. Within-Group Standard Deviation of the Change in the Logarithm of the PNF

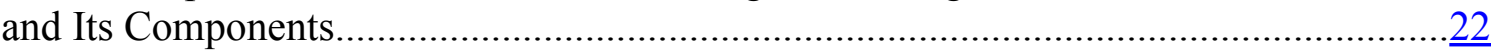

4. Correlation Matrix between the Change in the Logarithm of the Components

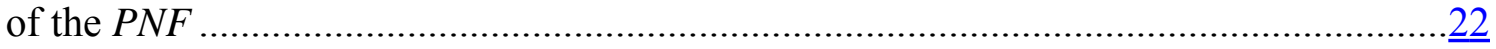

5. Correlations between the Change in the Logarithm of the $P N F$ and Its Components ..........22

6. Correlation Matrix Between the Change in the Logarithm of the PNF,

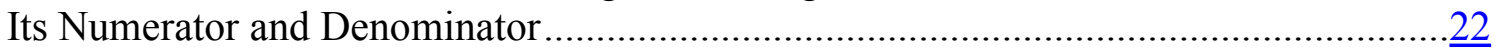

7. Correlation Matrix Between the $P N F$ and Other Financial Vulnerability Indicators ...........23

8. Probabilities of Default Conditional on Financial Vulnerability Indicators ....................... 23

9. Logit Estimates of Default Probabilities Without Fixed Effects ....................................24

10. Prediction Score Matrices Based on the Logit Estimates Without Fixed Effects.............. 25

11. Logit Estimates of Default Probabilities with Fixed Effects ......................................... $\frac{27}{28}$

12. Prediction Score Matrices Based on the Logit Estimates with Fixed Effects....................28

Figures

1. Estimated Cumulative Probability of Default for Different $P N F$ Values..........................16

Appendices

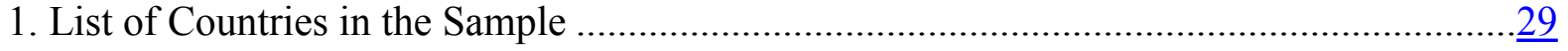

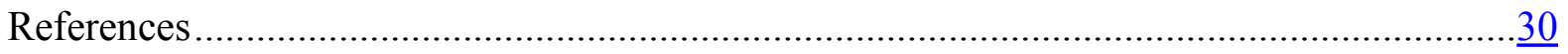




\section{INTRODUCTION}

This study contributes to a growing literature analyzing the determinants of default on foreign debt. We construct a new financial vulnerability indicator, consistent with the insights of the theoretical literature, that helps predict sovereign defaults. In addition, it allows us to compare financial vulnerability across countries and over time in order to assess and forecast probabilities of default.

When and why does a sovereign borrower default on its foreign debt? Clearly, this happens when available foreign resources fall short of needs. Even if the debt-to-GDP or debt-toexports ratio is high, expectations of a default are likely to be low when debt service is low. In addition, if the costs of default are high, a sovereign is likely to simply roll over its debt, even under significantly worse terms. Policymakers seem to prefer to avoid default even if that implies running down reserves, shortening the maturity of the debt, and ceding part of their economic policy sovereignty to multilateral institutions. This suggests that a default occurs when the government is in a vulnerable situation owing to high debt service so a deterioration in economic fundamentals leads to a negative change in creditor expectations and a sudden stop in capital flows follows.

A large gap between uses and sources of foreign currency is likely to be an important determinant of when a sovereign suffers a loss of market access. To reduce the financing gap, a sovereign could commit to limiting domestic consumption and adjust the level of imports in order to avoid a default. However, such a commitment may not be credible or possible, since taking the needed policy measures is costly in welfare terms. These large welfare costs, together with the costs of a default, may explain why a sovereign continues to honor its debts when it loses market access by using international reserves or special loans from multilateral institutions. When these run out, the sovereign incurs a default.

We construct an indicator of financial vulnerability, the proportion of new financing needs $(P N F)$, based on the above considerations. The indicator we propose is a measure of how much new financing is needed to pay the debt service and support the current level of imports, taking into account the availability of foreign currency income and assets, i.e., exports, transfers, and reserves. We argue that the vulnerability of a sovereign to a crisis increases with the ratio of new financing that is needed relative to the amount of available resources. In addition to this vulnerability indicator, we control for shocks that could trigger a confidence crisis by including variables such as GDP growth, terms of trade, and foreign interest rates. We also include other financial vulnerability indicators to see if they contain information that our indicator misses. Among them are the ratios of debt to GDP and exports; the ratios of debt service and short-term debt to reserves; and the current account balance.

We find that the $P N F$ is helpful in explaining and forecasting a large proportion of default episodes. In addition, several of the other financial vulnerability indicators included in previous work, such as the ratios of debt to exports and short-term debt to reserves, are not significant when they are included in cross-country estimations along with the PNF. The only 
one that seems to matter in a consistent way across countries, in addition to $P N F$, is the ratio of long-term debt service to reserves.

Our results have important implications for the optimal level of international reserves, strategies for debt management, and debt sustainability assessments. They suggest that the optimal level of international reserves is related to both the level of amortizations and the current account deficit. A debt structure that leads to low debt servicing will translate into a lower probability of default. Finally, debt sustainability assessments for emerging market countries have centered on the stabilization of the debt-to-GDP ratio. Unfortunately, they often lack an assessment of the vulnerability associated with the level at which the ratio stabilizes. Our empirical analysis, as well as several of the studies mentioned in the literature review, attempts to determine the level of vulnerability indicators for which default is more likely while, at the same time, emphasizing the probabilistic character of a debt crisis. We find that sovereign default is closely related to the external financing needs of a country. This allows us to assess relative vulnerability across countries and over time without having to take a position on what the optimal debt-to-GDP ratio should be.

The structure of this paper is as follows. Section II includes a brief review of the theoretical and empirical studies on determinants of defaults. Section III discusses the construction of the indicator of new financing needs, as well as its properties. Section IV reports the results from econometric estimations. Section $\mathrm{V}$ concludes and discusses the policy implications of our results.

\section{LITERATURE REVIEW: THEORETICAL AND EMPIRICAL RESULTS}

\section{A. Theoretical Analysis of Sovereign Debt Defaults}

There is an extensive literature on financial crises and sovereign debt defaults. A general characteristic of this literature is that it tries to explain discontinuities such as a sudden stop in capital flows, a run on reserves of the central bank, or a run on the deposits of a commercial bank. In general, these events occur when the institution facing a run is vulnerable and doubts about its creditworthiness arise. Thus, expectations of the institution's future actions, those of other creditors, and future shocks play a crucial role in explaining these extreme events.

Most studies agree on the importance of expectations and find that the probability of a crisis increases with financial vulnerability. However, there are substantial differences as to the source of the shocks driving a crisis and whether it is avoidable in the absence of major policy adjustments. Thus, they have different policy and welfare implications.

A first set of models, including the first-generation Krugman (1979) model, argues that fluctuations in economic fundamentals and bad government policies are the primary sources of crises. If there is a shock and the country is in a vulnerable situation, then a crisis occurs as the holders of that country's liabilities try to dispose of them. These models imply that a crisis is inevitable unless there is a major policy adjustment that improves creditworthiness. 
In its absence, support from an international financial institution (IFI) will only delay the crisis.

Krugman (1998) and Corsetti, Pesenti, and Roubini (1998) argue that the Asian currency and financial crises of 1997 reflected structural and policy problems. Market overreaction and herding only made the inevitable crises deeper. Detragiache and Spilimbergo (2001) show that a liquidity crisis can arise in a model with uncertainty and shocks. In their model, sovereign default is the only equilibrium in response to a large negative output shock. This occurs because the cost of default is smaller at lower levels of output.

A second set of crisis models, related to Obstfeld (1996), argues that multiple equilibria are possible and that a change in expectations not grounded in a sharp deterioration of fundamentals, i.e., a shock to a sunspot variable, can lead to a crisis. In this case, the change in expectations can occur due to coordination failures and herding. Avoiding these crises requires a coordination of expectations in the good equilibrium and not necessarily an adjustment in policies, so support from an IFI can be very effective.

Most recent sovereign debt models have been of the second type. For example, Calvo (1988) uses a Barro-Gordon-type model, where multiple equilibria arise given the lack of a precommitment strategy of the government. In one equilibrium, a welfare-maximizing government finds it optimal to repudiate or inflate away the debt. The multiple equilibria can be eliminated by using indexed financial instruments or establishing a ceiling for interest rates.

Perhaps more relevant for our purpose are several papers where multiple equilibria depend directly on the amount of debt that is being refinanced. In a two-period model, Alesina, Prati, and Tabellini (1990) show that the need of the government to roll over its debt can lead to multiple equilibria, even when faced with a cost of default. However, increasing the maturity of the debt can remove the crisis equilibrium. Cole and Kehoe $(1996,2000)$ identify similar results in a multi-period setting when it is possible for the government to default at any point in time. In their case, default will depend on the amount of debt to be serviced and the realization of a sunspot variable. As the amount of debt to be serviced is reduced, the probability of a confidence crisis also falls. Other related papers on self-fulfilling debt crises that emphasize debt service and liquidity problems include Giavazzi and Pagano (1990) and Detragiache (1996). Chang and Velasco (1998, 2000, 2001) explore foreign creditor runs when the debtors are domestic banks instead of the government. In contrast to several of the other papers, Chang and Velasco find an explicit insurance role for international reserves, which are likely to be run down if the bad equilibrium occurs. A general criticism of these models is made by Morris and Shin (2000), who show how multiple equilibria in crises models might disappear under certain types of uncertainty.

Whether default occurs as a unique equilibrium or as a bad equilibrium in a multiple equilibrium setting, the expectations of default in these models arise because the sovereign cannot credibly commit to reducing the population's consumption levels to repay the debt. Thus, these models suggest that expectations of a default, and a sudden stop in the supply of 
new financing, depend on two factors: the amount of debt that needs to be rolled over and the effect on consumption and welfare of following adjustment policies to repay the debt in the absence of new financing. These two concerns are incorporated in the indicator discussed in Section III. ${ }^{2}$

\section{B. Empirical Analysis and Forecasting of Debt Defaults}

There is also a burgeoning empirical literature analyzing the factors that lead to defaults and balance of payments crises. The following is a review of recent studies that have focused on the issue of default.

Cohen's (2000) study is motivated by an attempt to analyze the effects of the HIPC (Heavily Indebted Poor Countries) Initiative. Its starting point is the search for solvency thresholds, some minimum benchmark at which debt can be interpreted as being too large. He attempts to identify these in several ways. First, he calculates the average debt level at which countries experienced crises. In the 1980s, this occurred when the debt-to-exports ratio rose to 270 percent. Second, he computes the upper limit to the debt-to-GDP ratio consistent with the maximum amount of resources transferred abroad as debt service. In the 1980s, the major Latin American debtors' peak debt-to-GDP ratios reached 80 percent. Third, he looks at maximum primary surpluses achieved in the past to gauge the debt-to-tax ratios. He notes that large surpluses with respect to GDP were achieved by Belgium (10 percent), Italy (12 percent), and Ireland (15 percent). From these figures he extrapolates a maximum debtto-tax revenue ratio of 300 percent. His final approach is the estimation of the risk of a crisis on the basis of various indebtedness indicators. He estimates a probit model in which the probability of rescheduling is regressed on the beginning period debt-to-GDP ratio, a measure of the liquidity of the economy, an openness variable, and a dummy variable for Latin America. ${ }^{3}$ He finds that the probability of rescheduling is positively related to the ratio of debt to GDP and negatively related to both the degree of openness and the liquidity of the economy. Latin American countries are found to be more likely to reschedule.

Paladino and Stein (2001) try to find a threshold for optimal foreign debt in a world of uncertainty. They construct a theoretical model where agents maximize utility over a series of two-period cycles in which the productivity of investment is stochastic in the second period. A default occurs if consumption in the second period is less than some minimum threshold. Given the distribution of productivity shocks, they calculate the maximum level of debt. $^{4}$ They then calibrate this model for a set of 21 countries that rescheduled debt and

\footnotetext{
${ }^{2}$ Our analysis does not allow us to distinguish if the change in expectations that leads to a sudden stop is easily reversible because both types of models can be consistent with a crisis occuring in a situation of financial vulnerability.

${ }^{3}$ His sample covers rescheduling that occurred in the 1970s and 1980s.

${ }^{4}$ Productivity of capital is taken as the inverse of the incremental capital-output ratio.
} 
13 countries that did not reschedule over the period 1980-99. They find that the level of debt per se is not a good predictor of rescheduling. However, they create a variable, $D E F$, which is the difference between the actual level of debt and the maximum predicted by their model. Countries that rescheduled had values for $D E F$ that were positive and large or rising over time.

Reinhart (2002) looks at the ability of rating agencies to predict currency crises and defaults over the period 1979-99. She finds a strong link between currency crises and defaults for emerging market countries. The probability of having a currency crisis following a default is 61 percent, while the probability of defaulting following a currency crisis is 46 percent. This is consistent with the behavior of credit rating agencies, which downgrade a country following a currency crisis, recognizing the increased probability of default. Reinhart argues that in emerging market countries, large depreciations are contractionary, and access to international credit is lost, sparking a default. The credit rating agencies, however, do poorly in predicting currency crises and are outperformed by indicators of economic fundamentals.

The Appendix to IMF (2002) notes that when debt crises occur, they typically do so at debtto-GDP ratios of 50-60 percent. It estimates a binary recursive tree in which a level of debtto-GDP is chosen to discriminate between countries that do and do not default. The data used cover all IMF members, except for industrial countries, in five-year averages over the period 1979-2001. ${ }^{5}$ A debt-to-GDP ratio of 40 percent is found to minimize the Type I and Type II errors. For countries below this threshold, the conditional probability of a debt crisis is only 2-5 percent. The conditional probability rises to $15-20$ percent for countries above the threshold.

Detragiache and Spilimbergo (2001) examine the role of liquidity as a determinant of default. They present a probit analysis on a sample of 69 countries over 1971-98 where the dependent variable is the occurrence of a debt crisis. Crises are defined by the accumulation of arrears exceeding 5 percent of total commercial debt or a debt-restructuring agreement. There are 54 debt crises in the sample. The explanatory variables in the baseline regression are liquidity indicators (short-term debt, debt service, and reserves), debt indicators (the debtto-GDP ratio, the proportion of debt at concessional rates, the proportion of debt owed to multilateral lenders, world interest rates), and macroeconomic variables (a measure of openness and the overvaluation of the real exchange rate). They find that the less liquid a country is, the more likely it is to default. The probability of default also increases with the size of the debt and with the proportion of debt owed to multilateral lenders (perhaps because countries with problems are more likely to seek multilateral assistance). Countries with overvalued exchange rates and relatively small tradable goods sectors are more likely to default.

${ }^{5}$ Transition countries are included for the period 1994-2001. 
Catão and Sutton (2002) argue that volatility is a key determinant of default. In their study of 25 emerging market countries over the period 1970-2001, they examine the role of externally induced volatility (terms of trade shocks) and policy volatility (fiscal policy, monetary policy, and regulatory controls on foreign exchange transactions). The authors estimate a logit model that includes GDP growth, the ratio of debt service to exports, the ratio of net international reserves to debt, the fiscal balance, the real U.S. interest rate, and the real effective exchange rate. These variables are found to have significant explanatory power. However, the predictive power of the model is increased by adding proxies for external and policy volatility. With the inclusion of three policy volatility variables, their model predicts 16 of the 19 crises in their sample and gives no false alarms. ${ }^{6}$ Given that the variability of fiscal policy makes a large marginal contribution to the probability of default, they suggest that countries would do well to insulate economic policy from politics. This can be done by giving the central bank independence, increasing public sector transparency, and enacting fiscal responsibility laws.

Reinhart, Rogoff, and Savastano (2003; hereafter, RRS) argue that sovereign debt crises occur at ratios of debt to GDP and debt to exports that depend on the past history of debt service. If a country has defaulted in the past, it suffers from a loss of reputation, so investors lending to the country demand higher premiums. In addition, a sudden stop becomes likely at lower ratios of debt to GDP and debt to exports, compared with countries that have not defaulted. There seems to be an increase in the likelihood of a debt crisis at a debt-to-GDP ratio of close to 40 percent for countries that have defaulted in the past. However, as noted by Sims (2003) in his comments to RRS, the likelihood of having a ratio above 40 percent and not defaulting remains quite high. At the other extreme, when the ratio of debt to exports is 400 percent or higher, the probability of not defaulting is low, but many defaults occur at lower levels.

Manasse, Roubini, and Schimmelpfennig (2003) use three methods to examine defaults: an event study, a logit early warning system (EWS), and a binary recursive tree. They define a country as being in crisis if it is classified as being in default by Standard and Poor's or if it received a nonconcessional IMF loan in excess of 100 percent of quota. Their event studies show that, in a run-up to a crisis, both debt and debt service increase, the current account deficit widens, GDP growth slows, and inflation picks up. They estimate an EWS model for a data set consisting of 37 economies with market access for the period 1976-2001. They find that the likelihood of a crisis is explained by a combination of external debt indicators, macroeconomic conditions, and political economy factors. Their 16-variable model correctly predicts 74 percent of the 31 crises and sends false alarms in only 6 percent of the cases. In addition, almost half the false alarms are actually "early alarms," with the crises occurring one year later. When crises are redefined to include only defaults as defined by Standard and Poor's, the model correctly predicts 63 percent of the entries, while sending false alarms in

\footnotetext{
${ }^{6}$ The authors date their crises using the classification proposed in Beim and Calomiris (2001).
} 
4 percent of the cases. Finally, the authors use a binary recursive tree to search for nonlinear relationships between the variables of interest. They find that episodes of high debt and high inflation incur the largest default risk. Countries with intermediate levels of debt but that have serious liquidity problems and face political uncertainty, and those whose exchange rate regimes are relatively inflexible, also incur large default risk. The tree correctly predicts 89 percent of all crises, but sends false alarms in 19 percent of the cases. In 14 percent of the false alarms, the crises occur one year later.

IMF (2003) tries to estimate a more parsimonious model with explanatory variables that are easier to forecast using the same data set as used in Manasse, Roubini, and Schimmelpfennig. It relates the probability of a crisis to only three variables: the external debt ratio, the ratio of short-term debt to reserves, and the country's trade openness. The model predicts 88 percent of debt crises at the cost of a high percentage of false alarms (about 50 percent). Raising the trigger probability from 0.2 to 0.6 , the false alarms fall to 9 percent, but the share of crisies called correctly falls to 52 percent.

There is considerable heterogeneity in the empirical literature on estimating default probabilities. The various studies differ in their samples. Some cover only countries with market access while others also include countries whose primary source of external finance is official bilateral lenders. Moreover, there are differences about what defines a default. Some studies use the accumulation of arrears, others use reschedulings or default classifications by rating agencies, and some studies augment their definition by including large IMF programs. However, the common message in this literature is that default is positively related to some measure of debt or debt service.

\section{AN INDICATOR OF NEW FINANCING NEEDS}

\section{A. Construction of the Indicator}

Our indicator of financial vulnerability is based on three observations: (i) sovereigns tend not to default in periods when they are not required to make payments, (ii) sovereigns avoid a default if new financing is available and (iii) the theoretical literature suggests that the probability of a sudden stop depends on how much new financing is required to roll over the debt and maintain the current level of consumption.

We define our indicator of financial vulnerability as:

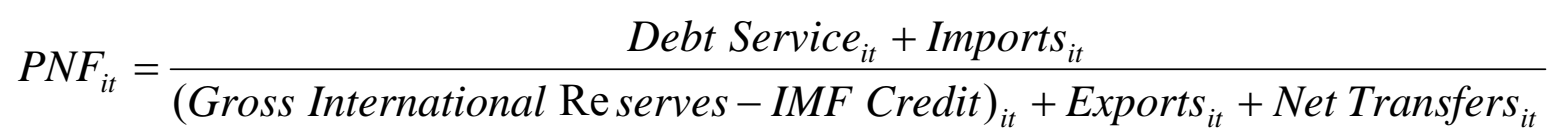

where $P N F$ stands for proportion of new financing needs and shows the proportion by which current uses of foreign income exceed current foreign resources. A value larger than unity implies that uses are larger than resources, so new foreign financing is needed in order to avoid a default or an import adjustment. Subscript $i$ is an index for countries and $t$ stands for 
the time period. The uses of foreign currency are service on long-term debt (interest and amortization), the stock and interest payments on short-term debt, and imports of goods and services. The denominator includes the country's sources of foreign currency: international reserves net of IMF credit, exports of goods and services, and net foreign transfers. ${ }^{7}$

The $P N F$ is clearly related to other indicators used in previous studies. Many of its components have been included in some form in estimations of the probability of foreign debt defaults and balance of payments crises. However, instead of having the partial ratios of debt service or imports or short-term debt to exports or reserves, we have a single ratio that incorporates all of these variables. Therefore, the current expression explicitly recognizes that foreign resources are fungible and that a sovereign can find it costly to adjust both debt service and imports. This implies that new foreign financing is needed to support both quantities and a default can ensue in the absence of a welfare-reducing adjustment of imports. ${ }^{8}$

\section{B. Data Sample and Sources}

Our sample is composed of annual data from 42 countries spanning the period 1970-2001 (or less when observations are not available for a given country), for a total of 662 observations and an average number of 15.8 years per country. ${ }^{9}$ There are several options to choose from as indicators of default. For example, Detragiache and Spilimbergo (2001) use episodes when at least 5 percent of the debt falls into arrears or is restructured. An alternative criteria is used by Beim and Calomiris (2001), who argue that the debt needs to be in arrears for a certain period of time. Manasse, Roubini, and Schimmelpfennig (2003) classify debt being in default if Standard and Poor's rates it as non performing or if the country receives a large loan from the IMF. This is analogous to the inclusion of large losses of reserves or increases in domestic interest rates in the analysis of exchange rate crises.

\footnotetext{
${ }^{7}$ Remittances are a large and stable source of finance for many countries. See Chami, Fullenkamp and Jahjah (2003) and Khartabil (2003).
}

${ }^{8}$ Alternative definitions of the $P N F$ were used in the econometric analysis. They all include the same components but their position in the numerator and denominator was shifted. The original definition of the $P N F$ does the best job in terms of significance, log likelihood and pseudo $R^{2}$. A complementary interpretation of the indicator from a time series point perspective is that gross capital inflows are mean reverting, with large capital inflows eventually falling in response to confidence shocks and leading to a default. In this interpretation, the $P N F$ works as a proxy for gross capital flows as a proportion of own resources.

${ }^{9}$ The list of countries is shown in Appendix I. The time period for transition economies starts in 1995. 
In this study, we rely on Standard and Poor's to determine when a country is in default. This leads to 26 defaults in the sample. We do not define episodes of large IMF support as defaults, as this can allow us to verify whether a default that is expected with a high probability can be avoided by the use of such resources. Finally, observations after a default are excluded from the sample until Sandard \& Poor's rates the debt as fully performing.

Data sources used for the components of the PNF are the World Bank's World Debt Tables for debt service; the IMF's World Economic Outlook (WEO) for exports, imports, and net transfers; and the IMF's International Financial Statistics (IFS) for net international reserves. In addition, variables that proxy for fundamentals or as possible triggers for a change in confidence include GDP growth (WEO), the change in the growth rate of the terms of trade (WEO), export growth (WEO) and the level of three-month treasury-bill interest rates in the United States (FRB). ${ }^{10}$ Finally, we include other indicators of financial vulnerability that have been used in the literature such as total external debt to GDP and to exports, short-term external debt to reserves, long-term debt service to reserves and to GDP, and the current account deficit to GDP (all from the World Debt Tables).

\section{Descriptive Statistics and Evolution of the Indicator over Time}

Summary statistics for the $P N F$ variable are reported in Table 1 . These are conditional on not being in default for more than one year-i.e., they exclude all years subsequent to the initial default until the debt is rated again as fully performing. At the sample mean, uses of foreign currency exceed own sources by 15 percent. The median shortfall is smaller, at 11 percent. For the top 25 percent of the observations, debt service and imports exceed own resources by at least 35 percent, while at the highest 10 percent of the distribution countries need to obtain new financing in excess of 60 percent of reserves, exports, and transfers. The two extremes of the sample are a country that needed new financing equivalent to twice its own resources and a country for which reserves, exports, and imports are 3 times the value of imports and debt service.

There is strong evidence that the variable has both kurtosis and positive skewness compared with a normal distribution. ${ }^{11}$ The variable's standard deviation is 0.363 , with a between

${ }^{10} \mathrm{We}$ also included interest rates or spreads on corporate bonds rated Baa in the United States in order to capture changes in risk premia. They were not found to be significant determinants of default when treasury-bill interest rates were included. The use of EMBI (Emerging Market Bond Index) spreads would have implied a large reduction in the number of observations. Some of these variables are also related with the cost of default in the theoretical literature. The cost of default is specified as a positive function of GDP as creditors are able to impose more costly sanctions. The same argument applies to the level and price of exports, as a disruption in trade becomes more costly. Finally, a higher foreign interest rate reduces the opportunity cost from losing access to international capital markets.

${ }^{11}$ Normality tests reject this at the 99 percent confidence level. 
groups standard deviation of 0.225 and a within group standard deviation of 0.275 . This last result suggests that the $P N F$ has substantial fluctuations for a given sovereign over time.

Understanding the degree of persistence and the sources of volatility in the indicator is important to assess if the vulnerability of a country can change quickly, which of the components of the indicator explains most of the variation and finally if a country is able to reduce its vulnerability. In order to assess persistence, we estimated an autorregresive equation for each of the countries of the sample for which we had 15 or more nondefault observations. $^{12}$ Table 2 summarizes our results. The average autoregressive coefficient (0.758) suggests that the indicator is stationary, though there is a significant amount of persistence as shocks to the $P N F$ have a half life of 2.5 years. ${ }^{13}$

We analyze the variance and correlations of the different components of our indicator. Ideally, this should be done on a country-by-country basis, but we did this for the sample as a whole due to the short time series for individual countries. In order to control for the scale and the fact that the components of the indicator are likely to have unit roots or trends, we express the variables as differences of logarithms and look only at the variance or correlation within groups, i.e., deviations from country means. Table 3 shows the standard deviation of growth rates of the $P N F$, its denominator, numerator and each of the components. ${ }^{14}$ The standard deviation of the denominator is higher than that of the numerator due to the volatility of net reserves, the most volatile of all the components. In contrast, exports have the lowest standard deviation of all the variables. Looking at the numerator, debt service is the second most volatile variable, while the standard deviation of the growth of imports is slightly larger than that of exports.

Table 4 shows the correlations between the different components of the PNF. All the correlations are positive, but those between debt service and all other components are low. In contrast, there are high and significant correlations between exports and imports, and exports and net reserves. Table 5 shows the correlations between the components and the PNF. As expected by construction, the correlations of the $P N F$ with the components of the numerator

${ }^{12}$ Unit root tests were not carried out given the extremely small sample size by country and the low power of these tests. Panel unit root tests have problems that can lead to bias and inconsistency of the estimators (see Moon and Perron (2003) and Moon, Perron, and Phillips (2003)).

${ }^{13}$ We also estimated an AR(2) specification. The coefficient on the second lag was significant for only 5 countries out of 22 . In the 5 significant cases, the coefficient on the second lag was negative. However, this does not seem a general result, since the nonsignificant estimates of the second lag for the rest of the countries were overwhelmingly positive.

${ }^{14}$ With the exception of net transfers, which are negative in several cases. 
are positive and the opposite holds for the components of the denominator. However, the individual correlations are higher in absolute value for the components of the denominator: net reserves and exports. Table 6 shows the correlations between the $P N F$, the numerator, and the denominator. This confirms the results from Tables 4 and 5. There is a positive correlation between the numerator and the denominator and the absolute value of the correlation with the $P N F$ is larger for the denominator. This suggests that a large proportion of the fluctuations in our indicator are due to movements in reserves and exports that reinforce each other.

Finally, we analyze the correlation between the $P N F$ and other financial vulnerability indicators that have been used in previous studies. Table 7 shows a significant and high, in absolute value, correlation between the $P N F$ and other vulnerability indicators, with the exception of the debt indicators constructed as ratios to GDP. In addition, the correlation with the $P N F$ is the highest for all the variables with three exceptions: long-term debt service to reserves, for which the correlation with the $P N F$ is the second highest, and the two debt indicators constructed as ratios to GDP. Therefore, it appears that the $P N F$ is a nonlinear combination of several of the other indicators that captures a substantial amount of their variability.

\section{ESTIMATION AND StATISTICAL RESUltS}

\section{A. Probability of Default Conditional on Different Vulnerability Indicators}

Table 8 shows the conditional probabilities of default for different subsamples of the $P N F$ indicator as well as another six indicators commonly used in other studies. The subsamples are the upper 50, 25, 10, and 5 percent of the observations. By "upper" we mean the values for which theory and previous empirical studies suggest that the conditional probability of default should increase.

Table 8 shows that, for any subsample, the conditional probability of a crisis is highest when it is conditioned on the value of the $P N F$. The probabilities are also high when conditioning by the ratio of short-term debt to reserves and the long-term debt service to reserves. If a country ranks in the top 5 percentile of the $P N F$ indicator-i.e., it has a shortfall of 80 percent or more of its own resources - it faces a probability of default in excess of 20 percent in the subsequent year. If we adjust our sample to consider large IMF support packages or defaults in the following two years as defaults, the conditional probability of default for a country in the uppermost 5 percentile rises to 42 percent. $^{15}$

${ }^{15}$ Pakistan is a notable outlier. For most of the 1980s, it had a high $P N F$ value yet it neither defaulted nor received large support from the IMF. In 1982 Pakistan became the fourth largest recipient of military aid from the United States (see Rose and Matinuddin (1989)). In addition, there was a substantial amount of Arab aid flowing at the time (see Rubin (1995)). When Pakistan is excluded, the conditional probability increases to 80 percent. 


\section{B. Logit Specification and Results}

A multivariate logit specification was used to estimate the probability of default. Given that default is a low-frequency event, a logit was preferred to a probit model. The method of estimation is maximum likelihood, with and without fixed effects. ${ }^{16}$ The variables included in the estimation are the $P N F_{i t}$; a set of fundamentals $X_{i t}$, which are meant to capture shocks to the economy that could trigger a default; and $F V_{i t}$, a set of other financial vulnerability indicators. $^{17}$

The set $X_{i t}$ includes GDP growth, the change in the rate of growth of the terms of trade, growth of exports and interest rates on three-month treasury-bills in the United States. In order to avoid problems of endogeneity, GDP and export growth were only included in lagged form, while contemporary values and lags were included for the terms of trade and foreign interest rates. ${ }^{18}$ The set $F V_{i t}$ includes the following ratios: foreign debt to GDP, the current account deficit to GDP, debt to exports, long-term debt service to reserves, long-term debt service to GDP, and short-term debt to reserves. They are always included in lagged form. 19

The results without fixed effects are shown in Table 9. Column (1) shows the results when no financial vulnerability indicators are included-i.e., only $X_{i t}$ is used. Column (2) adds the set $F V_{i t}$, but not the $P N F$. The results in column (3) are for the specification in which $P N F$ is substituted for all the other financial indicators. The preferred specification is presented in column (4), which excludes the financial vulnerability indicators that are insignificant when the $P N F$ is included. Estimations were also done by interacting the $P N F$ with debt to GDP and debt to exports, since it is possible that the supply of financing is only sensitive to the total scale of debt to GDP when there are substantial refinancing needs. These interactive terms were found to be insignificant and their sign was negative-i.e., opposite from what was expected.

\footnotetext{
${ }^{16}$ Random effects in this case provide the same results as the estimation without fixed effects.
}

${ }^{17}$ Estimations were also carried out using gross, instead of net, reserves in the calculation of $P N F$. While this leads to an improvement in the fit of the regressions, this occurs because of episodes when countries were forecasted to default on the basis of net reserves, but did not because of a large IMF loan.

${ }^{18}$ GDP growth was the only variable for which a second lag was significant. The lag of the change in terms of trade growth was not significant, while the contemporary value of the interest rate in the U.S. was not significant when its lag is included.

${ }^{19}$ The second lag of these variables was never significant. 
The results in column (1) are consistent with those found in other studies. The variables have the expected signs and are significant. When any of the financial vulnerability indicators are included, this initial set of variables retain their significance. The inclusion of the set $F V_{i t}$ of variables leads to a large improvement of fit, as seen in the pseudo $R^{2}$ and the log likelihood statistics (column 2). However, the significance of the individual indicators varies substantially, being low for debt and debt service to GDP and debt to exports, while debt service and short-term debt to reserves are strongly significant. The results in column (3) show that adding the $P N F$ leads to improvements in the pseudo $R^{2}$ and the log likelihood statistics similar to those from the inclusion of the other financial vulnerability indicators. Finally, when these vulnerability indicators are included together with the $P N F$, only longterm debt service to reserves remains significant. This may be due to the higher variability of this last indicator, as the profile of the $P N F$ is smoothed due to the inclusion of exports, transfers and imports. Adding long-term debt service to reserves to the estimation that includes the $P N F$ only results in a small improvement in fit. ${ }^{20}$

The change in the probability of default with respect to changes in the different variables, captured by the statistic $d F / d x$ evaluated at the mean values, is large for changes in the rate of growth of GDP and in U.S. interest rates. Moreover, changes in the $P N F$ have a large and highly nonlinear effect on the probability of defaults given the higher volatility of this variable. Figure 1 shows the estimated cumulative probability of a default at different values of the PNF, corresponding to the results in column (4). These are shown when the other variables are at their means and also for negative or positive shocks to these variables. ${ }^{21}$ When the other variables are at their means, the probability of defaults remains below 5 percent for values of the $P N F$ that are lower than 2 . The probability increases sharply from then on, to 15 percent at a $P N F$ of 2.5 and 40 percent at a $P N F$ of 3 . In addition, negative shocks sharply increase the probability of default for a given vaule of the $P N F$. At a $P N F$ of 1.5 , the negative shock leads to an increase in the probability of default from 1.4 to 8.4 percent. At a $P N F$ of 2.5 , the increase is from 15 to 54 percent. A positive shock reduces the probability of default, though the magnitude of the change is smaller than that arising from the negative shock. This analysis suggests that high values of the $P N F$ leave countries highly vulnerable to negative shocks.

${ }^{20}$ We separated the $P N F$ into two ratios, one with debt service and one with imports, in order to assess if one of these components was more relevant as a determinant of defaults. When both are included the ratio with imports is no longer significant, but this is likely due to multicollinearity as the correlation between the two ratios is high. $F$ tests suggest that both variables have explanatory power and tests of the equality of coefficients of the two ratios are unable to reject this at a 95 percent confidence level.

${ }^{21}$ The positive disturbance was constructed by choosing the value for all other variables which corresponds to the 25 percentile in the direction in which the probability of default is reduced. The construction of the unfavorable shock is analogous, though in the opposite direction. 
Figure 1. Estimated Cumulative Probability of Default for Different $P N F$ Values (evaluated at mean values of the other variables and for positive and negative shocks)

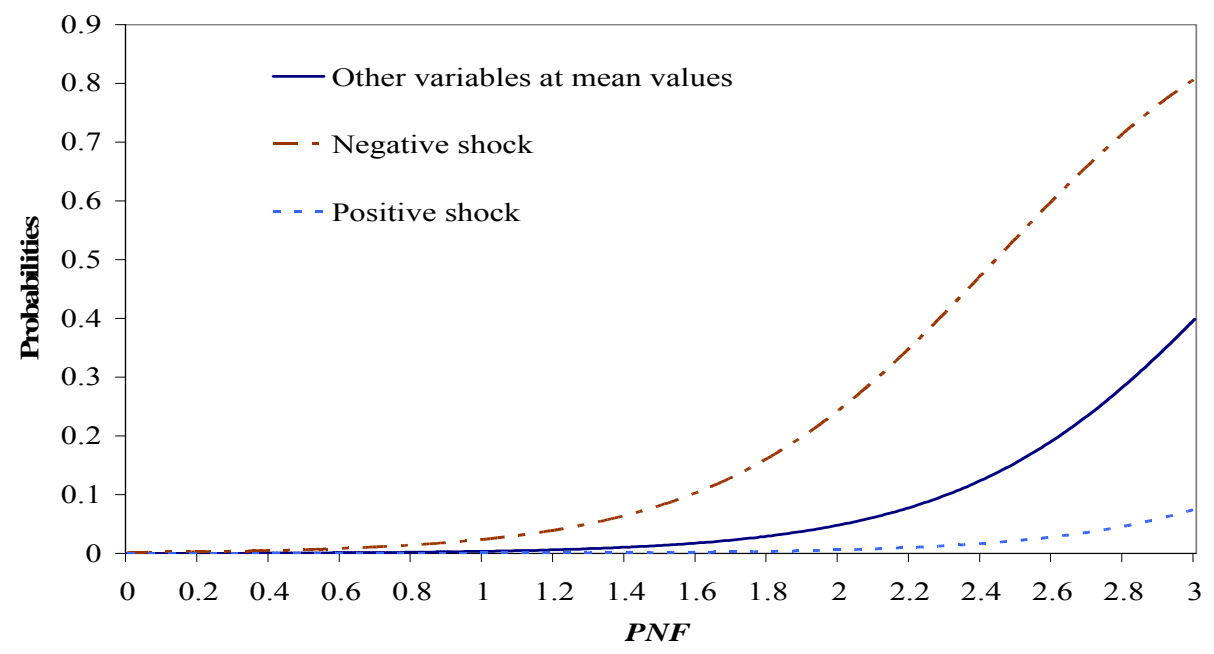

Table 10 shows the prediction score matrices associated with the four specifications reported in Table 9. As expected, a reduction of the probability threshold used in the score matrices leads to a larger number of correct crisis forecasts though at the cost of erroneously forecasting a larger number of nondefault episodes. The worst scores are clearly those associated with the specification reported in column (1), including only the variables in $X_{i t}$. The specification that uses the other vulnerability indicators, corresponding to column (2), does better for a high threshold value than that using the results from column (3), which use only the $P N F$, but this is reversed as the threshold is lowered. This is also true of the specification with the PNF and debt service to reserves reported in column (4) of Table 5. Finally, we recalculated the last score matrix by reclassifying as defaults large IMF support packages and defaults that occurred a year later than predicted. Making these adjustments, we find that the score matrices improve substantially at lower probability thresholds.

The decision of which threshold to use depends on which error is to be minimized. ${ }^{22}$ In most cases, reducing the threshold from 0.5 to 0.25 leads to a subtantial improvement in the number of correct forecasts of default episodes, with only a small increase in the number of nondefault episodes that are forecasted incorrectly. While reducing the threshold further, from 0.25 to 0.1 , also improves the number of correctly forecasted defaults, there is a significant increase in the number of incorrectly forecasted nondefault episodes. For example, in the case of the last score matrices reported in Table 10, which correspond to the modified classification of defaults, the number of correctly forecasted default episodes increases from 71 percent to 88 percent when lowering the threshold from 0.25 to 0.1 .

${ }^{22}$ Given the extremely low probability of a default in our sample, it is to be expected that low probability thresholds are needed to capture a substantial amount of the crises. 
However, the number of nondefault episodes that are forecasted incorrectly increases from less than 1 percent to almost 5 percent.

The estimations with fixed country effects have the serious drawback of leading to a large reduction in sample size, as all the countries that never defaulted fall out of the estimation. For those countries, the fixed effect is a perfect predictor of no default. Thus, the number of countries and observations fall by 44 percent and 42 percent, respectively. In addition, the estimations with fixed effects do not allow us to identify cross-country threshold levels of the indicators at which the probability of a default is high. This may explain why this type of estimations have generally not been reported in previous studies. Nevertheless, the results are suggestive as to why the $P N F$ seems to outperform other indicators, and why indicators such as the debt and current account to GDP are not found to be significant in estimations without fixed effects. The results are reported in Table 11.

The results excluding the financial variables are very similar to those obtained without fixed effects (see column 1). However, the results when including the financial variables are substantially different. ${ }^{23}$ The coefficient on the $P N F$ remains highly significant and is of the same magnitude as before. However, the coefficients on several of the other financial variables increase and become significant. Debt service to reserves remains highly significant and its coefficient increases three fold. In addition, debt to GDP and to exports are significant and the current account deficit marginally so.

The fixed effects estimations suggest that increases in the level of debt, relative to GDP and exports, and a wider current account deficit effectively lead to higher probabilities of default. However, the levels at which this occurs differ by country. In contrast, the absolute value of the $P N F$ is related with the probability of a crisis in both types of estimations, allowing for cross-country comparisons.

Table 12 has prediction score matrices associated with the fixed effects estimations. Those corresponding to the specification with only the $X_{i t}$ set of variables do not show any significant improvement with respect to that without fixed effects, though the results should be interpreted cautiously given the different sample. The inclusion of the financial vulnerability indicators leads to a very substantial improvement, even with respect to the best specification without fixed effects. Finally, when early default predictions and substantial IMF support are classified as default episodes, forecast errors become very small. In the case

${ }^{23}$ Short-term debt to reserves was excluded from this specification as it was very highly correlated with the $P N F$. This is to be expected because debt service and reserves are the most volatile components of the $P N F$, driving movements with respect to the mean. Debt service to GDP is also excluded given that it was never found to be significant. For comparison purposes, estimations without fixed effects were carried out for this reduced sample. The results are qualitatively similar to those for the full sample without fixed effects, though the current account balance is significant when the $P N F$ is not included. 
of a 0.25 percent threshold, 87 percent of default episodes are forecasted correctly at a cost of only 1.2 percent of non-default episodes being forecasted incorrectly. When the threshold is lowered to 0.1 percent, all the default episodes are forecasted correctly but at a cost of 3 percent of incorrect non default forecasts.

\section{Conclusions And Policy Implications}

Our model contributes to the growing body of empirical work on predicting defaults and distinguishes itself from previous work in a number of ways. First, it uses a variable that is meant to correspond more closely to the implications of the theoretical literature on financial crises. While we have not attempted to provide rigorous micro-foundations for our econometric model, we have based it on the insights of the first- and second-generation crises literature. We have combined both financial vulnerability, proxied for by the proportion of new financing needs $(P N F)$, and shocks to fundamentals or expectations in a model of sovereign default. The insight of our model is that a weak financial position, i.e., the need for substantial external finance, together with difficulties adjusting imports, leaves a country vulnerable to changes in expectations.

Second, relative to previous research, our model is parsimonious. It consists of a constant and seven additional explanatory variables. Previous research has tended to use a larger number of explanatory variables. Indeed, some studies appear to overfit the data since the number of explanatory variables is large relative to the number of crises. ${ }^{24}$ Third, our explanatory variables are largely drawn from balance of payments and other macroeconomic datainformation which is relatively easy to obtain for most countries.

Third, a comparison between the estimation results with and without fixed effects indicates that the $P N F$ is a good indicator to assess financial vulnerability across countries, relative to other indicators such as debt to GDP or the current account balance. However, the results using fixed effects indicate that changes in these variables do increase the probability of default, although the levels at which they lead to a high likelihood of crisis differs across countries. Finally, the indicator is simple and intuitive. Essentially, it measures the amount of foreign resources a country needs over the amount of resources it has.

Our results have implications for the optimal level of reserves, debt management strategies, and the assessment of debt sustainability. The level of international reserves ought to be compared with both the current account deficit and the level of amortizations in order to assess the probability of default. For example, the conditional probabilities indicate that a country with a $P N F$ value below the median has only a 1 percent probability of default. An assessment of the optimal level of reserves needs to take into account the reduction in the

${ }^{24}$ In some of the previous studies, the number of crises is small relative to the number of explanatory variables, making it difficult to assess the significance of the included variables. See Sharma (1999) for a discussion. 
probability of a default versus the cost of holding those reserves. An alternative is that the country chooses to lengthen the maturity of external debt so that amoritizations are low at any point in time. ${ }^{25}$

The papers in the literature explaining defaults differ depending on the definition of defaults, explanatory variables used and methods of estimation. However, they generally describe default as a probabilistic event, where the probabilities can be estimated with reference to some debt or debt-service indicator. This conclusion, which is supported by our model, has implications for the concept of debt sustainability and how it is assessed.

The current approach to analyzing debt sustainability is based on the intertemporal budget constraint (IBC). ${ }^{26}$ Given a consistent set of macroeconomic assumptions, the debt burden is seen as sustainable if the debt-to-GDP ratio declines over time. While our results with fixed effects show that a reduction in the debt-to-GDP ratio leads to a fall in the probability of default they also suggest, as do many of the other empirical studies, that there is no robust relationship between a particular level of the debt-to-GDP ratio and the probability of a default. Thus, if sustainability is interpreted as a low probability of default, a specific level of debt service and imports relative to available foreign resources is more relevant.

An alternative definition of sustainability can take into account the effect that a given level of debt has on economic growth through crowding out of investment and exports as well as expectations of an increasing tax burden in the future. While this is related with the possibility of a confidence crisis, the concepts are different. This approach seems more closely related with that taken to assess the maximum level of indebtedness consistent with good growth performance and economic policies.

For example, the HIPC Initiative focuses on reducing debt to a sustainable level, which is explicitly defined as the ratio of the net present value (NPV) of debt to exports below 150 percent, or a ratio of NPV debt to fiscal revenues of 250 percent. It is considered that higher debt burdens impede the adoption of adequate policies and growth. Similarly, the Maastricht criteria for accession to the European Union include an explicit debt-to-GDP ratio of 60 percent. In this case, the threshold seems related with the effect that a high debt-toGDP ratio could have in terms of increasing future tax burdens, given that a reduction in the value of debt through inflation is no longer feasible. However, our results suggest that there is significant heterogeneity across countries in the levels at which debt has an effect on economic performance.

25 This strategy for debt management has also been suggested in some of the theoretical literature. For example, see Cole and Kehoe (2000).

${ }^{26}$ For a useful derivation and analysis of the IBC, see Horne (1988). 
Our results also suggest a number of problems with the IBC approach. First, even if the debt burden is falling, it may still be "too high" and leave the country excessively vulnerable to confidence crises depending on the structure of amortizations. Second, while stress tests can be carried out to assess the effect of shocks on debt ratios, they do not provide the increase in the probability of default associated with a higher debt ratio. An assessment of default probabilities is necessary to interpret and draw policy implications from the stress tests.

Third, the analysis is often undertaken in terms of the debt-to-GDP ratio. This presupposes that it will be possible to transform domestic income into sufficient foreign currency to service the debt. It also assumes that the nominal exchange rate is constant and does not vary with indebtedness. This may not be the case. We believe that the ratio of foreign currency payments to foreign currency receipts, which underlies the $P N F$, is a better indicator.

An extension of this paper would be to study the improvement in the PNF between the time when a country defaults and when it normalizes its debt situation. Such an examination could address a number of questions. Does a county's $P N F$ improve substantially from the default period to that when the debt becomes fully performing again? If an initial improvement is observed, is it followed by additional reductions in the PNF or does it typically increase? Does the size of the initial improvement matter for the future evolution of the PNF? 
Table 1. Summary Statistics of the Proportion of New Financing Needs

\begin{tabular}{rr|lr} 
& & & \\
\hline Mean & $115.18 \%$ & Standard deviation & 0.363 \\
Median & $110.71 \%$ & Within groups & 0.275 \\
Percentiles & & Between groups & 0.225 \\
$10 \%$ & $74.95 \%$ & & \\
$25 \%$ & $89.28 \%$ & Number of observations & 662 \\
$75 \%$ & $134.82 \%$ & Number of countries & 42 \\
$90 \%$ & $160.26 \%$ & Average years per country & 15.8 \\
& & & \\
Skewness & 1.025 & Kurtosis & 5.142 \\
\hline
\end{tabular}

Table 2. Summary of Results from AR(1) Regressions of the Proportion of New Financing Needs by Country

Results from autoregressive equations

of the following form:

$P N F_{i t}=\beta_{0}+\rho P N F_{i t-1}+\varepsilon_{i t}$

\begin{tabular}{l|r}
\hline Number of countries & 22 \\
$\quad$ with 15 observations or more & 22.3 \\
Average number of years & \\
& 0.758 \\
Average of estimated $\rho$ & 0.183 \\
Standard deviation of estimated $\rho$ & \\
Half life at the average $\rho$ & 2.50 \\
\hline
\end{tabular}


Table 3. Within-Group Standard Deviation of the Change in the Logarithm of the $P N F$ and Its Components

\begin{tabular}{|c|c|c|c|c|c|c|c|}
\hline & PNF & $\begin{array}{c}\text { Net Reserves }+ \\
\text { Exports }+ \text { Net } \\
\text { Transfers } \\
\end{array}$ & Net Reserves & Exports & $\begin{array}{l}\text { ebt Service + } \\
\text { Imports }\end{array}$ & Debt Service & Imports \\
\hline $\begin{array}{l}\text { Within group standard } \\
\text { deviation }\end{array}$ & 0.169 & 0.178 & 0.416 & 0.157 & 0.149 & 0.263 & 0.173 \\
\hline
\end{tabular}

Table 4. Correlation Matrix Between the Change in the Logarithm of the Components of the $P N F$

\begin{tabular}{l|cccc} 
& Debt Service & Imports & Net reserves & Exports \\
\hline Debt Service & 1 & & & \\
Imports & 0.263 & 1 & & \\
Net reserves & 0.103 & 0.229 & 1 & 1 \\
Exports & 0.176 & 0.563 & 0.407 &
\end{tabular}

Table 5. Correlations Between the Change in the Logarithm of the PNF and Its Components

\begin{tabular}{l|cccc} 
& Debt Service & Imports & Net Reserves & Exports \\
\hline$P N F$ & 0.341 & 0.261 & -0.523 & -0.447
\end{tabular}

Table 6. Correlation Matrix Between the Change in the Logarithm of the $P N F$, Its Numerator and Denominator

\begin{tabular}{c|ccc} 
& $P N F$ & Debt service + imports & $\begin{array}{c}\text { Net reserves + exports }+ \\
\text { net transfers }\end{array}$ \\
\hline$P N F$ & 1 & & \\
Debt service + imports & 0.377 & 1 & 1 \\
$\begin{array}{c}\text { Net reserves + exports }+ \\
\text { net transfers }\end{array}$ & -0.622 & 0.491 &
\end{tabular}


Table 7. Correlation Matrix Between the PNF and Other Financial Vulnerability Indicators

\begin{tabular}{|c|c|c|c|c|c|c|c|}
\hline & $P N F$ & Debt/GDP & Debt/exports & $\begin{array}{c}\text { Short-term } \\
\text { debtreserves }\end{array}$ & $\begin{array}{c}\text { LTdebt } \\
\text { service/GDP }\end{array}$ & $\begin{array}{c}\text { LTdebt } \\
\text { servicerreserves } \\
\end{array}$ & $\begin{array}{c}\text { Gurrentaccount } \\
\text { balance/GDP }\end{array}$ \\
\hline$P N F$ & 1 & & & & & & \\
\hline $\mathrm{Debt/GDP}$ & 0.243 & 1 & & & & & \\
\hline Debtexports & 0.452 & 0.373 & 1 & & & & \\
\hline $\begin{array}{c}\text { Short-term } \\
\text { debtreserves }\end{array}$ & 0.680 & 0.212 & 0.294 & 1 & & & \\
\hline LT debt service/GDP & 0.132 & 0.650 & 0.007 & 0.050 & 1 & & \\
\hline $\begin{array}{c}\text { LTdebt } \\
\text { service/reserves }\end{array}$ & 0.573 & 0.238 & 0.236 & 0.641 & 0.446 & 1 & \\
\hline $\begin{array}{l}\text { Current account } \\
\text { balance/GDP }\end{array}$ & -0.488 & -0.097 & -0.130 & -0.184 & -0.008 & -0.163 & 1 \\
\hline
\end{tabular}

Table 8. Probabilities of Default Conditional on Financial Vulnerability Indicators

\begin{tabular}{|c|c|c|c|c|c|c|c|}
\hline Frequencyfor: & $P N F$ & Debt/GDP & Debt/exports & $\begin{array}{c}\text { Short-term } \\
\text { debt/reserves }\end{array}$ & $\begin{array}{c}\text { LTdebt } \\
\text { service/GDP }\end{array}$ & $\begin{array}{c}\text { LTdebt } \\
\text { service/reserves }\end{array}$ & $\begin{array}{c}\text { Current account } \\
\text { balance/GDP }\end{array}$ \\
\hline $\begin{array}{c}\text { Wholesample } \\
n=662\end{array}$ & $3.93 \%$ & $3.93 \%$ & $3.93 \%$ & $3.93 \%$ & $3.93 \%$ & $3.93 \%$ & $3.93 \%$ \\
\hline $\begin{array}{c}\text { Percentile } 50 \% \\
n=331\end{array}$ & $\begin{array}{l}\mathbf{6 . 9 5 \%} \\
(>111 \%)\end{array}$ & $\begin{array}{l}\mathbf{5 . 7 4 \%} \\
(>35 \%)\end{array}$ & $\begin{array}{l}\mathbf{6 . 3 4 \%} \\
(>199 \%)\end{array}$ & $\begin{array}{l}6.04 \% \\
(>60 \%)\end{array}$ & $\begin{array}{l}\mathbf{5 . 7 4 \%} \\
(>4.3 \%)\end{array}$ & $\begin{array}{l}6.04 \% \\
(>48 \%)\end{array}$ & $\begin{array}{l}\mathbf{6 . 3 4 \%} \\
(<-3.0 \%)\end{array}$ \\
\hline $\begin{array}{c}\text { Percentile } 25 \% \\
n=166\end{array}$ & $\begin{array}{l}10.30 \% \\
(>135 \%)\end{array}$ & $\begin{array}{l}\mathbf{8 4 3 \%} \\
(>48 \%)\end{array}$ & $\begin{array}{l}\mathbf{8 . 4 3 \%} \\
(>318 \%)\end{array}$ & $\begin{array}{l}\mathbf{1 0 . 3 0 \%} \\
(>115 \%)\end{array}$ & $\begin{array}{l}7.23 \% \\
(>6.6 \%)\end{array}$ & $\begin{array}{l}9.70 \% \\
(>88 \%)\end{array}$ & $\begin{array}{l}\mathbf{6 . 0 2 \%} \\
(<-5.5 \%)\end{array}$ \\
\hline $\begin{array}{c}\text { Percentile } 10 \% \\
n=66\end{array}$ & $\begin{array}{l}\mathbf{1 8 . 1 8 \%} \\
(>160 \%)\end{array}$ & $\begin{array}{c}\mathbf{1 3 . 6 4 \%} \\
(>61 \%)\end{array}$ & $\begin{array}{l}1212 \% \\
(>454 \%)\end{array}$ & $\begin{array}{l}\mathbf{1 5 . 1 5 \%} \\
(>195 \%)\end{array}$ & $\begin{array}{l}8.96 \% \\
(>9.1 \%)\end{array}$ & $\begin{array}{l}16.42 \% \\
(>141 \%)\end{array}$ & $\begin{array}{l}\mathbf{7 . 4 6 \%} \\
(<-8.6)\end{array}$ \\
\hline $\begin{array}{c}\text { Percentile } 5 \% \\
n=33\end{array}$ & $\begin{array}{l}21.21 \% \\
(>180 \%)\end{array}$ & $\begin{array}{c}12.12 \% \\
(>67 \%)\end{array}$ & $\begin{array}{l}\mathbf{1 2 1 2 \%} \\
(>535 \%)\end{array}$ & $\begin{array}{l}\mathbf{1 7 . 6 5 \%} \\
(>267 \%)\end{array}$ & $\begin{array}{l}\mathbf{8 . 8 2 \%} \\
(>10.4 \%)\end{array}$ & $\begin{array}{l}\mathbf{1 7 . 6 5 \%} \\
(>188 \%)\end{array}$ & $\begin{array}{l}\mathbf{1 2 1 2 \%} \\
(<-10.3)\end{array}$ \\
\hline
\end{tabular}

Note: The numbers inparentheses indicate the criteriafor the value of the variablecorresponding to each percentile. 
Table 9. Logit Estimates of Default Probabilities Without Fixed Effects

\begin{tabular}{|c|c|c|c|c|c|}
\hline & & (1) & (2) & (3) & (4) \\
\hline Constant & $\begin{array}{l}\text { Coefficient } \\
\text { z Stat. } \\
(\mathrm{dF} / \mathrm{dx}) \\
\end{array}$ & $\begin{array}{r}-4.061 \\
-6.850\end{array}$ & $\begin{array}{r}-6.559 \\
-6.420\end{array}$ & $\begin{array}{r}-7.657 \\
-7.540\end{array}$ & $\begin{array}{r}-7.939 \\
-7.270\end{array}$ \\
\hline GDP growth rate (first lag) & $\begin{array}{l}\text { Coefficient } \\
\text { z Stat. } \\
(\mathrm{dF} / \mathrm{dx}) \\
\end{array}$ & $\begin{array}{r}-0.101 \\
-2.110 \\
-0.170 \\
\end{array}$ & $\begin{array}{r}-0.156 \\
-2.800 \\
-0.093 \\
\end{array}$ & $\begin{array}{r}-0.155 \\
-2.930 \\
-0.109 \\
\end{array}$ & $\begin{array}{r}-0.156 \\
-2.830 \\
-0.089 \\
\end{array}$ \\
\hline GDP growth rate (second lag) & $\begin{array}{l}\text { Coefficient } \\
\text { z Stat. } \\
(\mathrm{dF} / \mathrm{dx})\end{array}$ & $\begin{array}{r}-0.106 \\
-2.140 \\
-0.178 \\
\end{array}$ & $\begin{array}{r}-0.148 \\
-2.420 \\
-0.088 \\
\end{array}$ & $\begin{array}{r}-0.158 \\
-2.780 \\
-0.111 \\
\end{array}$ & $\begin{array}{r}-0.143 \\
-2.360 \\
-0.081 \\
\end{array}$ \\
\hline Growth in terms of trade (difference) & $\begin{array}{l}\text { Coefficient } \\
\text { z Stat. } \\
(\mathrm{dF} / \mathrm{dx}) \\
\end{array}$ & $\begin{array}{r}-2.533 \\
-1.960 \\
-0.043 \\
\end{array}$ & $\begin{array}{r}-4.148 \\
-2.630 \\
-0.025 \\
\end{array}$ & $\begin{array}{r}-3.955 \\
-2.750 \\
-0.028 \\
\end{array}$ & $\begin{array}{r}-4.372 \\
-2.940 \\
-0.025 \\
\end{array}$ \\
\hline U.S. T-bill interest rate (first lag) & $\begin{array}{l}\text { Coefficient } \\
\text { z Stat. } \\
(\mathrm{dF} / \mathrm{dx}) \\
\end{array}$ & $\begin{array}{r}0.250 \\
3.780 \\
0.422 \\
\end{array}$ & $\begin{array}{r}0.196 \\
2.470 \\
0.117 \\
\end{array}$ & $\begin{array}{r}0.201 \\
2.730 \\
0.141 \\
\end{array}$ & $\begin{array}{r}0.221 \\
2.860 \\
0.126 \\
\end{array}$ \\
\hline Export growth rate (first lag) & $\begin{array}{l}\text { Coefficient } \\
\text { z Stat. } \\
(\mathrm{dF} / \mathrm{dx})\end{array}$ & $\begin{array}{r}-0.045 \\
-3.000 \\
-0.076\end{array}$ & $\begin{array}{r}-0.044 \\
-2.380 \\
-0.026 \\
\end{array}$ & $\begin{array}{r}-0.043 \\
-2.640 \\
-0.031 \\
\end{array}$ & $\begin{array}{r}-0.048 \\
-2.810 \\
-0.027 \\
\end{array}$ \\
\hline$P N F$ (first lag) & $\begin{array}{l}\text { Coefficient } \\
\text { z Stat. } \\
(\mathrm{dF} / \mathrm{dx}) \\
\end{array}$ & & & $\begin{array}{r}3.072 \\
5.260 \\
0.022 \\
\end{array}$ & $\begin{array}{r}2.563 \\
4.050 \\
0.015 \\
\end{array}$ \\
\hline Debt/GDP (first lag) & $\begin{array}{l}\text { Coefficient } \\
\text { z Stat. } \\
(\mathrm{dF} / \mathrm{dx}) \\
\end{array}$ & & $\begin{array}{r}0.008 \\
0.420 \\
0.005 \\
\end{array}$ & & \\
\hline Current account balance/GDP (first lag) & $\begin{array}{l}\text { Coefficient } \\
\text { z Stat. } \\
(\mathrm{dF} / \mathrm{dx}) \\
\end{array}$ & & $\begin{array}{r}-0.089 \\
-1.530 \\
-0.053 \\
\end{array}$ & & \\
\hline Debt/exports (first lag) & $\begin{array}{l}\text { Coefficient } \\
\text { z Stat. } \\
(\mathrm{dF} / \mathrm{dx}) \\
\end{array}$ & & $\begin{array}{r}0.001 \\
1.040 \\
0.001 \\
\end{array}$ & & \\
\hline LT debt service/GDP (first lag) & $\begin{array}{l}\text { Coefficient } \\
\text { z Stat. } \\
(\mathrm{dF} / \mathrm{dx}) \\
\end{array}$ & & $\begin{array}{r}0.091 \\
0.770 \\
0.054 \\
\end{array}$ & & \\
\hline LT debt service/reserves (first lag) & $\begin{array}{l}\text { Coefficient } \\
\text { z Stat. } \\
(\mathrm{dF} / \mathrm{dx}) \\
\end{array}$ & & $\begin{array}{r}0.604 \\
1.740 \\
0.004 \\
\end{array}$ & & $\begin{array}{r}0.760 \\
2.730 \\
0.004 \\
\end{array}$ \\
\hline ST Debt/reserves (first lag) & $\begin{array}{l}\text { Coefficient } \\
\text { z Stat. } \\
(\mathrm{dF} / \mathrm{dx})\end{array}$ & & $\begin{array}{r}0.674 \\
2.590 \\
0.004\end{array}$ & & \\
\hline Number of observations & & 632 & 632 & 632 & 632 \\
\hline Pseudo $R^{2}$ & & 0.23 & 0.41 & 0.39 & 0.42 \\
\hline Log likelihood & & -83.40 & -63.48 & -66.58 & -62.96 \\
\hline Number of countries & & 43 & 43 & 43 & 43 \\
\hline
\end{tabular}


Table 10. Prediction Score Matrices Based on the Logit Estimates Without Fixed Effects

Column (1): Specification with real variables

For threshold probability of 0.5

\begin{tabular}{|c|c|c|c|}
\hline \multirow[b]{2}{*}{$\underline{\text { Predicted }}$} & \multicolumn{3}{|l|}{ Actual } \\
\hline & 1 & & tal \\
\hline 1 & 2 & 1 & 3 \\
\hline 0 & 24 & 605 & 629 \\
\hline Total & 26 & 606 & 632 \\
\hline
\end{tabular}

Type I error

Type II error
For threshold probability of 0.25

\begin{tabular}{|c|c|c|c|}
\hline \multirow{3}{*}{$\begin{array}{r}\text { Predicted } \\
1\end{array}$} & \multicolumn{3}{|l|}{ Actual } \\
\hline & 1 & \multicolumn{2}{|c|}{0 Total } \\
\hline & 7 & 13 & 20 \\
\hline 0 & 19 & 593 & 612 \\
\hline Total & 26 & 606 & 632 \\
\hline
\end{tabular}

Type I error

Type II error

$73.1 \%$

$2.1 \%$
For threshold probability of 0.1

\begin{tabular}{|c|c|c|c|}
\hline \multirow{3}{*}{$\begin{array}{r}\text { Predicted } \\
1\end{array}$} & \multicolumn{3}{|l|}{ Actual } \\
\hline & 1 & & tal \\
\hline & 13 & 46 & 59 \\
\hline 0 & 13 & 560 & 573 \\
\hline Total & 26 & 606 & 632 \\
\hline
\end{tabular}

Type I error $\quad 50.0 \%$

Type II error $\quad 7.6 \%$

Column (2): Specification with vulnerability indicators excluding PNF

For threshold probability of 0.5

\begin{tabular}{|c|c|c|c|}
\hline \multirow[b]{2}{*}{ Predicted } & \multicolumn{3}{|l|}{ Actual } \\
\hline & 1 & & tal \\
\hline 1 & 9 & 3 & 12 \\
\hline 0 & 17 & 603 & 620 \\
\hline Total & 26 & 606 & 632 \\
\hline
\end{tabular}

Type I error $\quad 65.4 \%$

Type II error
For threshold probability of 0.25

\begin{tabular}{|c|c|c|c|}
\hline \multirow[b]{2}{*}{ Predicted } & \multicolumn{3}{|l|}{ Actual } \\
\hline & 1 & & \\
\hline 1 & 13 & 12 & 25 \\
\hline 0 & 13 & 594 & 607 \\
\hline Total & 26 & 606 & 632 \\
\hline
\end{tabular}

Type I error

Type II error
$50.0 \%$

$2.0 \%$
For threshold probability of 0.1

\begin{tabular}{|c|c|c|c|}
\hline \multirow[b]{2}{*}{ Predicted } & \multicolumn{3}{|l|}{ Actual } \\
\hline & 1 & & otal \\
\hline 1 & 16 & 40 & 56 \\
\hline 0 & 10 & 566 & 576 \\
\hline Total & 26 & 606 & 632 \\
\hline
\end{tabular}

Type I error $\quad 38.5 \%$

Type II error $\quad 6.6 \%$

\section{Column (3): Specification with only PNF}

For threshold probability of 0.5

\begin{tabular}{|c|c|c|c|}
\hline \multirow{3}{*}{$\begin{array}{r}\text { Predicted } \\
1\end{array}$} & \multicolumn{3}{|l|}{ Actual } \\
\hline & 1 & \multicolumn{2}{|c|}{0 Total } \\
\hline & 7 & 2 & 9 \\
\hline 0 & 19 & 604 & 623 \\
\hline Total & 26 & 606 & 632 \\
\hline
\end{tabular}

Type I error

Type II error

$$
\begin{array}{r}
73.1 \% \\
0.3 \%
\end{array}
$$

\begin{tabular}{|c|c|c|c|}
\hline \multirow{3}{*}{$\begin{array}{r}\text { Predicted } \\
1\end{array}$} & \multicolumn{3}{|l|}{ Actual } \\
\hline & 1 & \multicolumn{2}{|c|}{0 Total } \\
\hline & 14 & 12 & 26 \\
\hline 0 & 12 & 594 & 606 \\
\hline Total & 26 & 606 & 632 \\
\hline
\end{tabular}

For threshold probability of 0.25

Type I error

Type II error

$$
46.2 \%
$$

\begin{tabular}{|c|c|c|c|}
\hline \multirow{3}{*}{$\begin{array}{r}\text { Predicted } \\
1\end{array}$} & \multicolumn{3}{|l|}{ Actual } \\
\hline & 1 & \multicolumn{2}{|c|}{0 Total } \\
\hline & 18 & 41 & 59 \\
\hline 0 & 8 & 565 & 573 \\
\hline Total & 26 & 606 & 632 \\
\hline
\end{tabular}$$
2.0 \%
$$

For threshold probability of 0.1

Type I error $\quad 30.8 \%$

Type II error $\quad 6.8 \%$ 
Table 10. (concluded) Prediction Score Matrices Based on the Logit Estimates Without Fixed Effects

Column (4): Specification with $P N F$ and debt service/reserves

For threshold probability of 0.5

\begin{tabular}{|c|c|c|c|}
\hline \multirow[b]{2}{*}{ Predicted } & \multicolumn{3}{|l|}{ Actual } \\
\hline & 1 & & tal \\
\hline 1 & 8 & 3 & 11 \\
\hline 0 & 18 & 603 & 621 \\
\hline Total & 26 & 606 & 632 \\
\hline
\end{tabular}

Type I error

Type II error

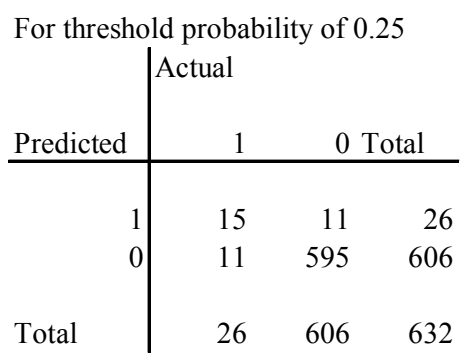

Type I error

Type II error

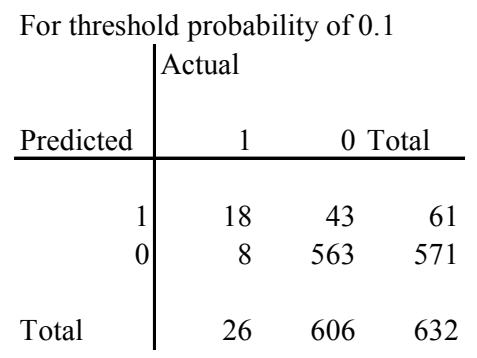

Type I error $\quad 30.8 \%$

Type II error $\quad 7.1 \%$

Column (4): Specification with $P N F$ and debt service/reserves.

Classifying IMF bailouts and crises in the following two years as true defaults.

For threshold probability of 0.5

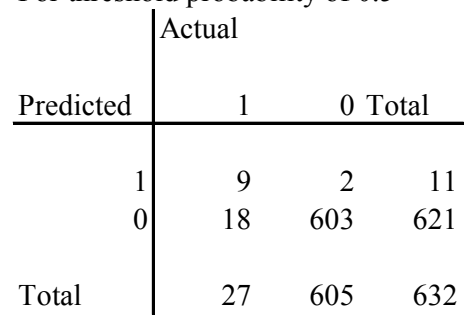

Type I error

Type II error
$66.7 \%$

$0.3 \%$
For threshold probability of 0.25

\begin{tabular}{|c|c|c|c|}
\hline \multirow[b]{2}{*}{ Predicted } & \multicolumn{3}{|l|}{ Actual } \\
\hline & 1 & & tal \\
\hline 1 & 23 & 4 & 27 \\
\hline 0 & 10 & 595 & 605 \\
\hline Total & 33 & 599 & 632 \\
\hline
\end{tabular}

Type I error

Type II error
$30.3 \%$

$0.7 \%$
For threshold probability of 0.1

\begin{tabular}{|c|c|c|c|}
\hline \multirow[b]{2}{*}{ Predicted } & \multicolumn{3}{|l|}{ Actual } \\
\hline & 1 & & otal \\
\hline 1 & 36 & 28 & 64 \\
\hline 0 & 5 & 563 & 568 \\
\hline Total & 41 & 591 & 632 \\
\hline
\end{tabular}

Type I error

$12.2 \%$

Type II error 
Table 11. Logit Estimates of Default Probabilities with Fixed Effects

\begin{tabular}{|c|c|c|c|}
\hline & & (1) & (2) \\
\hline GDP growth rate (first lag) & $\begin{array}{l}\text { Coefficient } \\
\text { z Stat. }\end{array}$ & $\begin{array}{r}-0.089 \\
-1.600\end{array}$ & $\begin{array}{r}-0.191 \\
-1.830\end{array}$ \\
\hline GDP growth rate (second lag) & $\begin{array}{l}\text { Coefficient } \\
\text { z Stat. }\end{array}$ & $\begin{array}{r}-0.101 \\
-1.610\end{array}$ & $\begin{array}{r}0.017 \\
0.160\end{array}$ \\
\hline Growth in terms of trade (difference) & $\begin{array}{l}\text { Coefficient } \\
\text { z Stat. }\end{array}$ & $\begin{array}{r}-2.112 \\
-1.700\end{array}$ & $\begin{array}{r}-4.886 \\
-2.200\end{array}$ \\
\hline U.S. T-bill interest rate (first lag) & $\begin{array}{l}\text { Coefficient } \\
\text { z Stat. }\end{array}$ & $\begin{array}{r}0.236 \\
3.230\end{array}$ & $\begin{array}{r}0.387 \\
2.290\end{array}$ \\
\hline Export growth rate (first lag) & $\begin{array}{l}\text { Coefficient } \\
\text { z Stat. }\end{array}$ & $\begin{array}{r}-0.049 \\
-3.040\end{array}$ & $\begin{array}{r}-0.031 \\
-1.050\end{array}$ \\
\hline$P N F$ (first lag) & $\begin{array}{l}\text { Coefficient } \\
\text { z Stat. }\end{array}$ & & $\begin{array}{r}3.317 \\
2.570\end{array}$ \\
\hline Debt/GDP (first lag) & $\begin{array}{l}\text { Coefficient } \\
\text { z Stat. }\end{array}$ & & $\begin{array}{r}0.135 \\
2.880\end{array}$ \\
\hline Current account balance/GDP (first lag) & $\begin{array}{l}\text { Coefficient } \\
\text { z Stat. }\end{array}$ & & $\begin{array}{r}-0.254 \\
-1.690\end{array}$ \\
\hline Debt/exports (first lag) & $\begin{array}{l}\text { Coefficient } \\
\text { z Stat. }\end{array}$ & & $\begin{array}{r}0.006 \\
1.780\end{array}$ \\
\hline LT debt service/reserves (first lag) & $\begin{array}{l}\text { Coefficient } \\
\text { z Stat. }\end{array}$ & & $\begin{array}{r}2.239 \\
2.560\end{array}$ \\
\hline \multicolumn{2}{|l|}{ Number of observations } & 364 & $\overline{364}$ \\
\hline \multicolumn{2}{|l|}{ Log likelihood } & -46.49 & -19.98 \\
\hline \multicolumn{2}{|l|}{ Number of countries } & 24 & 24 \\
\hline
\end{tabular}




\section{Table 12. Prediction Score Matrices Based on the Logit Estimates with Fixed Effects}

Column (1): Specification with real variables

For threshold probability of 0.5

\begin{tabular}{|c|c|c|c|}
\hline \multirow[b]{2}{*}{ Predicted } & \multicolumn{3}{|l|}{ Actual } \\
\hline & 1 & & otal \\
\hline 1 & 7 & 0 & 7 \\
\hline 0 & 19 & 338 & 357 \\
\hline Total & 26 & 338 & 364 \\
\hline
\end{tabular}

Type I error

Type II error

$$
\begin{array}{r}
73.1 \% \\
0.0 \%
\end{array}
$$

\begin{tabular}{|c|c|c|c|}
\hline \multirow[b]{2}{*}{ Predicted } & \multicolumn{3}{|l|}{ Actual } \\
\hline & 1 & & otal \\
\hline 1 & 12 & 13 & 25 \\
\hline 0 & 14 & 325 & 339 \\
\hline Total & 26 & 338 & 364 \\
\hline
\end{tabular}

For threshold probability of 0.25

Type I error

Type II error

Column (2): Specification with all vulnerability indicators

\begin{tabular}{|c|c|c|c|}
\hline \multirow[b]{2}{*}{$\underline{\text { Predicted }}$} & \multicolumn{3}{|l|}{ Actual } \\
\hline & 1 & & tal \\
\hline 1 & 15 & 1 & 16 \\
\hline 0 & 11 & 337 & 348 \\
\hline Total & 26 & 338 & 364 \\
\hline
\end{tabular}

For threshold probability of 0.5

Type I error

Type II error

\begin{tabular}{|c|c|c|c|}
\hline \multirow[b]{2}{*}{ Predicted } & \multicolumn{3}{|c|}{ Actual } \\
\hline & 1 & & otal \\
\hline 1 & 20 & 9 & 29 \\
\hline 0 & 6 & 329 & 335 \\
\hline Total & 26 & 338 & 364 \\
\hline
\end{tabular}

For threshold probability of 0.25

Type I error

Type II error
$23.1 \%$

$2.7 \%$

\begin{tabular}{|c|c|c|c|}
\hline \multirow{3}{*}{$\begin{array}{r}\text { Predicted } \\
1\end{array}$} & \multicolumn{3}{|l|}{ Actual } \\
\hline & 1 & & tal \\
\hline & 17 & 42 & 59 \\
\hline 0 & 9 & 296 & 305 \\
\hline Total & 26 & 338 & 364 \\
\hline
\end{tabular}

For threshold probability of 0.1

Type I error $\quad 34.6 \%$

Type II error $\quad 12.4 \%$

Column (2): Specification with all vulnerability indicators. Classifying IMF bailouts and crises in the following two years as true defaults.

\begin{tabular}{|c|c|c|c|}
\hline \multirow[b]{2}{*}{ Predicted } & \multicolumn{3}{|l|}{ Actual } \\
\hline & 1 & \multicolumn{2}{|c|}{0 Total } \\
\hline 1 & 17 & 0 & 17 \\
\hline 0 & 10 & 337 & 347 \\
\hline Total & 27 & 337 & 364 \\
\hline
\end{tabular}

For threshold probability of 0.5

Type I error $\quad 37.0 \%$

Type II error

\begin{tabular}{|c|c|c|c|}
\hline \multirow[b]{2}{*}{ Predicted } & \multicolumn{3}{|l|}{ Actual } \\
\hline & 1 & & otal \\
\hline 1 & 27 & 4 & 31 \\
\hline 0 & 4 & 329 & 333 \\
\hline Total & 31 & 333 & 364 \\
\hline
\end{tabular}

For threshold probability of 0.25

Type I error

Type II error
$12.9 \%$

$1.2 \%$

\begin{tabular}{|c|c|c|c|}
\hline \multirow[b]{2}{*}{ Predicted } & \multicolumn{3}{|l|}{ Actual } \\
\hline & 1 & & tal \\
\hline 1 & 23 & 23 & 46 \\
\hline 0 & 3 & 315 & 318 \\
\hline Total & 26 & 338 & 364 \\
\hline
\end{tabular}

For threshold probability of 0.1

Type I error

$11.5 \%$

Type II error $\quad 6.8 \%$ 


\section{List of Countries in the Sample}

\begin{tabular}{ll} 
Algeria & Lithuania \\
Argentina & Malaysia \\
Bolivia & Mexico \\
Brazil & Morocco \\
Chile & Oman \\
China & Pakistan \\
Colombia & Paraguay \\
Costa Rica & Peru \\
Czech Republic & Philippines \\
Dominican Republic & Poland \\
Ecuador & Romania \\
Egypt & Russia \\
El Salvador & Slovak Republic \\
Estonia & South Africa \\
Hungary & Thailand \\
India & Trinidad and Tobago \\
Indonesia & Tunisia \\
Jamaica & Turkey \\
Jordan & Ukraine \\
Kazakhstan & Uruguay \\
Korea & Venezuela \\
Latvia & \\
\hline
\end{tabular}




\section{References}

Alesina, Alberto, Alessandro Prati, and Guido Tabellini, 1990, "Public Confidence and Debt Management: A Model and a Case Study of Italy," in Public Debt Management: Theory and History, ed. by Rudiger Dornbusch and Mario Draghi (New York, NY: Cambridge Univeristy Press).

Beim, David, and Charles Calomiris, 2001, Emerging Financial Markets (New York: McGraw Hill Irwin).

Calvo, Guillermo, 1988, "Servicing the Public Debt: The Role of Expectations," American Economic Review, Vol. 78, pp. 647-61.

Catão, Luis, and Bennet Sutton, 2002, “Sovereign Defaults: The Role of Volatility," IMF Working Paper 02/149 (Washington: International Monetary Fund).

Chami, Ralph, Connel Fullenkamp and Samir Jahjah, 2003, "Are Immigrant Remittance Flows a Source of Capital for Development," IMF Working Paper 03/189 (Washington: International Monetary Fund).

Chang, Roberto, and Andres Velasco, 1998, "Financial Fragility and the Exchange Rate Regime,” NBER Working Paper No. 6469 (Cambridge, Massachusetts: National Bureau of Economic Research).

—_ 2000, "Banks, Debt Maturity and Financial Crises," Journal of International Economics, Vol. 51, pp. 169-94.

_ 2 2001, "A Model of Financial Crises in Emerging Markets," Quarterly Journal of Economics, May, pp. 489-517.

Cohen, Daniel, 2000, “The HIPC Initiative: True and False Promises," OECD Development Centre, Technical Paper No. 166.

Cole, Harold, and Timothy Kehoe, 1996, “A Self-fulfilling Model of Mexico’s 1994-1995 Debt Crisis," Journal of International Economics, Vol. 41, pp. 309-30.

— , 2000, “Self-fulfilling Debt Crises," Review of Economic Studies, Vol. 67 (January), pp. 91-116.

Corsetti, Giancarlo, Paolo Pesenti, and Nouriel Roubini, 1998, "What Caused the Asian Currency and Financial Crises? Part I: The Macroeconomic Overview," NBER Working Paper No. 6833 (Cambridge, Massachusetts: National Bureau of Economic Research). 
Detragiache, Enrica, 1996, "Rational Liquidity Crises in the Sovereign Debt Market: In Search of a Theory," IMF Staff Papers, Vol. 43 (September), pp. 545-70.

— Interpretation,” IMF Working Paper 01/2 (Washington: International Monetary Fund).

Giavazzi, Francesco, and Marco Pagano, 1990, "Confidence Crises and Public Debt Management," in Public Debt Management: Theory and History, ed. by Rudiger Dornbusch and Mario Draghi (New York, NY: Cambridge Univeristy Press).

Horne, Jocelyn, 1988, “Criteria of External Sustainability,” IMF Working Paper 88/60 (Washington: International Monetary Fund).

International Monetary Fund, 2002, “Assessing Sustainability,” IMF Staff Report (May 28). Available via Internet: http://www.imf.org/external/np/pdr/sus/2002/ eng/052802.htm. See also Public Information Notice (PIN), No. 02/69: http://www.imf.org/external/np/sec/pn/2002/pn0269.htm.

_ , 2003, "Sustainability Assessments-Review of Application and Methodological Refinements," IMF Staff Report (July 10). Available via Internet: http://www/imf.org/external/np/pdr/sustain/2003/061003.htm. See also Public Information Notice (PIN) No. 03/111: http://www.imf.org/external/np/sec/pn/2003/ pn03111.htm.

Khartabil, Tala, 2003, "The Role of Remittances in Debt Sustainability: The Case of Lebanon," unpublished, IMF Institute (Washington: International Monetary Fund).

Krugman, Paul, 1979, “A Model of Balance of Payments Crises,” Journal of Money, Credit and Banking, Vol. 11 (August).

_ Technology.

Manasse, Paolo, Nouriel Roubini, and Axel Schimmelpfennig, 2003, "Predicting Sovereign Debt Crises," IMF Working Paper 03/221 (Washington: International Monetary Fund).

Moon, Hyungsik, and Benoit Perron, 2003, "Testing for a Unit Root in Panels with Dynamic Factors," CLEO Working Paper, USC.

_ , and Peter Phillips, 2003, "Incidental Trends and the Power of Unit Root Tests," unpublished (Yale University). 
Morris, Stephen, and Hyung Song Shin, 2000, "Rethinking Multiple Equilibria in Macroeconomic Modeling," NBER Macroeconomics Annual, Vol. 15, pp. 139-61.

Obstfeld, Maurice, 1996, "Models of Currency Crises with Self-Fulfilling Features," European Economic Review, Vol. 40, pp. 1037-47.

Paladino, Giovanna, and Jerome L. Stein, 2001, "Country Default Risk: An Empirical Assessment," CESifo Working Paper No. 469.

Reinhart, Carmen M., 2002, "Default, Currency Crises and Sovereign Credit Ratings," World Bank Economic Review, Vol. 16, pp. 151-70.

— Papers on Economic Activity 1, pp. 1-74.

Rose, Leo, and Kamal Matinuddin, eds., 1989, Beyond Afghanistan: The Emerging U.S.Pakistan Relations (Berkeley: University of California Press).

Rubin, Barnett, 1995, The Fragmentation of Afghanistan: State Formation and Collapse in the International System (New Haven: Yale University Press).

Sharma, Sunil, 1999, “The Challenge of Predicting Economic Crises," Finance \& Development, Vol. 36 (June), pp. 40-42.

Sims, Christopher, 2003, Comments on Reinhart, Carmen, Kenneth Rogoff, and Miguel Savastano, 2003, "Debt Intolerance," Brookings Papers on Economic Activity 1, pp. 63-66. 